\title{
ХЕЛАТНЫЕ КОМПЛЕКСЫ МЕДИ(ІІ) НА ОСНОВЕ ТЕРПЕНОВЫХ ПРОИЗВОДНЫХ ЭТИЛЕНДИАМИНА: СИНТЕЗ, АНТИОКСИДАНТНАЯ АКТИВНОСТЬ
}

\author{
О.А. Залевская' ${ }^{1}$ Я.А. Гурьева', О.Г. Шевченко² \\ ${ }^{1}$ Институт Химии ФИЦ Коми НЦ УрО РАН, \\ 167000, Россия, г. Сыктывкар, ул. Первомайская, д.48. \\ ${ }^{2}$ Институт биологии ФИЦ Коми НЦ УрО РАН, \\ 167982, Россия, г. Сыктывкар, ул. Коммунистическая, д.28.
}

DOI: 10.19163/MedChemRussia2021-2021-289

E-mail: zalevskayaoa@rambler.ru

Комплексы меди характеризуются большим потенциалом биомедицинского применения [1-4], который может быть обусловлен в том числе и их антиоксидантной активностью (АОА).

В настоящей работе впервые представлен синтез и сравнительная оценка антиоксидантных свойств новых хелатных комплексов меди (1-5) с терпеновыми производными этилендиамина. Синтез металлокомплексов 1-5 выполнен на основе ранее описанных иминов, полученных конденсацией этилендиамина с соответствующими карбонильными производными природных терпеноидов.

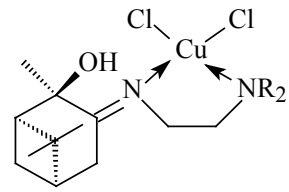

$\mathrm{R}=\mathrm{CH}_{3}(\mathbf{1}), \mathrm{H}(\mathbf{2})$

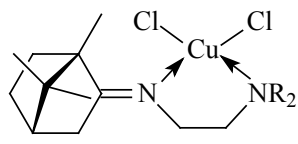

$\mathrm{R}=\mathrm{CH}_{3}(\mathbf{3}), \mathrm{H}(\mathbf{4})$

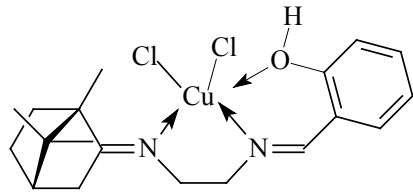

5

Для полученных соединений исследована антирадикальная активность в тесте с DPPH, AOA на субстрате, полученном из головного мозга лабораторных животных, антиоксидантные и мембранопротекторные свойства на модели $\mathrm{H}_{2} \mathrm{O}_{2}-и$ AAPH- индуцированного гемолиза эритроцитов. И при использовании в качестве субстрата окисления эмульсии, содержащей легкоокисляемые липиды головного мозга, и в экспериментах на живых клетках наибольшая АОА отмечена для металлокомплексов, которые превосходят соответствующие лиганды и в ряде случаев не уступают по активности стандарту - ионолу. Наиболее перспективным для более детального изучения биологической активности представляется ионный комплекс 5, содержащий N,N,O-донорный лиганд саленового типа.

\section{Литература}

[1] C. Duncan and A.R. White, Metallomics. 2012, 4, 127-138

[2] C. Santini, M. Pellei, V. Gandin et al., Chem. Rev. 2014, 114, 815-862

[3] G. Psomas, Coord. Chem. Rev. 2020, 412, e213259

[4] A.K. Patel, R.N. Jadeja, H. Roy et al., Polyhedron. 2020, 186, e114624 